DOI: $10.30519 /$ ahtr.571666

Advances in Hospitality and Tourism Research (AHTR)

\title{
GASTRONOMIC IDENTITY OF GAZIANTEP: PERCEPTIONS OF TOURISTS AND RESIDENTS
}

\author{
Belma SUNA ${ }^{1}$ \\ Tourism and Hotel Management, Gaziantep University, Gaziantep, Turkey \\ ORCID: 0000-0003-0710-2678 \\ Maria D. ALVAREZ \\ Department of Tourism Administration, Boğaziçi University, Istanbul, Turkey \\ ORCID: 0000-0003-4986-5702
}

\begin{abstract}
Tasting local flavours is often an important motivation for tourists visiting a particular destination. A destination's richness in terms of cuisine increases its attractiveness and may be an important element of its branding identity. Gaziantep is one of the cities that is known for its gastronomy and unique foods. The purpose of this research is to explore the concept of gastronomic identity, seeking to better understand the elements that construct it in the case of Gaziantep. In addition, the study looks at the differences between tourists and local residents in relation to the gastronomic identity of this city. According to the results, gastronomic identity is formed by four dimensions; namely Gastronomic Culture and Reputation, Food Quality, Food Outlets and Gastronomic Activities. Besides, significant differences between the tourists and residents are found in the dimensions of Food Quality and Gastronomic Activities.
\end{abstract}

Article History

Received 29 May 2019

Revised 22 November 2019

Accepted 5 December 2019

Keywords

gastronomic identity

stakeholders

Gaziantep

destination branding

destination marketing

\section{INTRODUCTION}

Traveling to a destination with the specific purpose of tasting its unique dishes has become increasingly common, and subsequently many researchers have focused on identifying the contribution of local food to

\footnotetext{
${ }^{1}$ Address correspondence to Belma Suna, Tourism and Hotel Management, Gaziantep University, Gaziantep, TURKEY.Email: suna@gantep.edu.tr
} 
tourism (Horng \& Tsai, 2010; Jiménez-Beltrán et al., 2016a; Kivela, 2017; Lai et al., 2018; Okumuş et al., 2018; Sirse, 2014; Sormaz et al., 2016; Stavrianea et al., 2017). Gastronomy tourism is defined as travel with the aim of experiencing the unique culinary specialities and traditions of a destination (Long, 2004). According to the World Tourism Organisation, gastronomy helps develop the communication between diverse cultures, facilitating multiculturalism (UNWTO, 2016). Gastronomy has become a fundamental component of travel (Cohen, 2003; Correia et al., 2008; Kivela \& Crotts, 2006) and a significant motivator for visiting a particular destination (McKercher et al., 2008). Indeed, when people choose a place to visit, they generally make a deep research about the presence and richness of the local foods during the decision-making phase (Okumuş et al., 2007; Boyne et al., 2003). Thus, gastronomy and unique food-related aspects of the place may become important resources that are used in the creation of a unique value proposition for the destination (Horng \& Tsai, 2012). According to Haugland et al. (2011), destinations' competitiveness is dependent on the place's ability to convert existing resources into competencies through the coordination of stakeholders' activities and inter-destination ties. Thus, following a resource-based view of destination development (Barney, 1996; Haugland et al., 2011; Horng \& Tsai, 2012), gastronomy and local food culture should be evaluated in relation to its potential to contribute to the destination's brand.

Given the importance of gastronomy and gastronomy tourism, a growing literature on the topic is emerging. While several papers analyse gastronomy tourism from the tourist's point of view (for example, Correia et al., 2008; Kivela \& Crotts, 2006), others have begun to look at the topic from the perspective of the destination's branding activity, with an examination of the gastronomic identity within the overall brand strategy of the destination (Lai et al., 2018; Lin at al., 2011). Thus, Fox (2007, p. 546) states that "a unique and memorable gastronomic identity is an indispensable strength to any successful tourist destination". Even though gastronomic identity is often viewed from the tourist's perspective, the point of view of the local people who help create the destination's experience is critical. In this sense, the role of residents in the creation of a destination's brand is considered as important, since local people are a part of the destination's experience, may act as ambassadors of the destination brand and may participate in the process of defining the destination's identity (Braun et al., 2013). A successful brand strategy is that which achieves an alignment of the views of local people with the image of place that is portrayed to tourists (Kong et al., 2015). 
Furthermore, the ability of the destination to coordinate and integrate the efforts of various actors is essential for the success of the destination, as well as that of the individual producers (Haugland et al., 2011).

There are many destinations known for the richness of their gastronomy worldwide. The increasing interest in gastronomy as a cultural element of the destination has led to the establishment of the UNESCO Creative Cities Network (UCCN) in 2004, incorporating gastronomy as one of the intangible heritage elements fostering the development of the destination via creativity and culture (Xiaomin, 2017). One of the cities included in this network is Gaziantep, which constitutes an example of an increasingly popular gastronomic destination in Turkey. It was included in 2015 in the UCCN network under the category of gastronomy. However, this destination is not only rich in gastronomical elements; it also encompasses a significant historical heritage derived from the existence of ancient civilizations and different cultures within its territory. Therefore, Gaziantep is a good example of a destination where historical, cultural and gastronomical elements interact to create a highly attractive tourism offering (Birdir et al., 2015). The current study aims to explore the concept of gastronomic identity as a destination's strategic competency that is based on existing culinary resources (Haugland et al., 2011), seeking to better understand the elements that construct it in the case of Gaziantep. In addition, the study also attempts to determine whether there are differences between tourists and residents in terms of their understanding of the gastronomic identity of the city, providing suggestions on how different culinary elements may come together to enhance the city's competency in terms of gastronomy.

\section{LITERATURE REVIEW}

\section{Gastronomy from a Resource-Based View of Destination Development}

Destinations are composed of amalgams of individual products that are combined to create an integrated experience for the tourists (Buhalis, 2000), thus generating the need for strategies that go beyond single organizational actors. According to a resource-based view of the firm (Barney, 1996) organizations become competitive when they are able to use their unique resources to create a sustained competitive advantage. However, destinations are faced with a situation in which multiple actors and levels of decision-making exist (Haugland et al., 2011). Thus, the destination's ability to turn the individual resources of each actor into 
destination competencies and to coordinate the actions of different players is paramount to achieve success (Haugland et al., 2011). Evaluating the destination's resources from the perspective of the resource-based theory of the firm can also provide insights to guide policy making and resource allocation (Duarte Alonso, 2017). For example, Duarte Alonso et al. (2018) use the resource-based theory of the firm to evaluate the potential of Peru as a culinary destination. In addition, as the destination evolves through different stages of its life cycle (Butler, 1980), so its resources and competencies may also change (Rodríguez-Díaz \& Espino-Rodríguez, 2008).

The resource-based view of the firm has been applied to the evaluation of gastronomy as an important competency that is based on the culinary resources of the destination (Horng \& Tsai, 2012). Gastronomy can be defined as a multifaceted process that encompasses choosing, cooking, serving and enjoying satisfying foods (Encyclopaedia Britannica, 2019). Accordingly, gastronomy may be thought to include reflexive eating and cooking, encompassing food preparation, production and presentation of different dishes with the aim of achieving excellence in this process (Hjalager \& Richards, 2002; Scarpato, 2000,2001; Symons 1998). As travellers are becoming more interested in getting detailed information about what they can eat at the destination, a new type of tourism which is based on the culinary qualities of the destination has emerged. Thus, gastronomy tourism may be defined as "travelling for the purpose of exploring and enjoying the destination's food and beverage and to savour unique and memorable gastronomy experiences" (Kivela \& Crotts, 2005, p. 42).

Gastronomy is considered as being a part of the destination's culture (Jiménez-Beltrán et al., 2016a), and is increasingly viewed in the literature as one of the main resources that the destination may have (Horng \& Tsai, 2012; Okumuş et al., 2007; Presenza \& Del Chiappa, 2013; Sánchez-Cañizares \& López-Guzman, 2012). According to a research carried out by the World Tourism Organization on a panel of tourism experts, gastronomy is considered a distinctive and strategic component in defining the image and brand of the destination and a driving force for tourism development (UNWTO, 2017). While eating food was formerly the first step in Maslow's needs hierarchy, it has now become a symbol of people's lifestyles. The food may be an indicator of prestige, also leading to the development of cuisine-based new lifestyles (Hjalager \& Richards, 2002; Horng \& Tsai, 2010; Kivela \& Crotts, 2006; Riley, 1994). This trend is compounded by the use of social media, since tourists share the pictures of 
the food they taste while on vacation, influencing other individuals' destination choices (Eröz \& Doğdubay, 2012; Tuç \& Özkanl1, 2017). Gastronomy tourism is thus favoured by those tourists who want to come across different culinary cultures and share their experiences with other individuals (Şahin \& Unver, 2015). As a result, gastronomical elements in the destination have become significant features to draw international and national tourists (Horng \& Tsai, 2010). Furthermore, many destinations use food components as a source of attraction, including these in their tourism marketing activities (Lin et al., 2011) to differentiate themselves from other competing places. Thus, the cuisine and culinary products at the destination may be considered as strategic resources that constitute a differentiating factor and a source of competitive advantage for the place (Okumus \& Çetin, 2018). The importance given and use of culinary resources in the destination's overall strategy is also dependent on the stage of the destination's life cycle (Harrington \& Ottenbacher, 2010). Using the case of Lyon as an example, Harrington and Ottenbacher (2010) remark that as destinations become more mature, they rely less on their culinary attributes for promotion.

Gastronomy tourism also supports regional development by linking food and beverages that are indigenous to the place to the tourism activity, thus strengthening local identity (Everett \& Aitchison, 2008). Each destination decides to focus on specific local foods and create food-related experiences that will be used to brand and market the place in order to attract tourists (Williams et al., 2014). However, this unique identity needs to be supported by overlapping elements at the destination that constitute the overall product (Willams et al., 2014).

\section{Gastronomic Identity of the Tourist Destination}

Gastronomic identity has been the subject of several research studies in recent years. Harrington is one of the first researchers to analyse the concept of gastronomic identity. According to Harrington (2005) the destination's gastronomic identity emerges from the environment and culture of the region, which affects the flavours and tastes in food and beverages. While geography and climate are part of the environment, ethnic and historical elements that form a part of the place's culture may affect tastes, food textures and flavours. Thus, environmental and cultural factors of the destination are influential in shaping the unique characteristics of the destination's cuisine, in other words, its gastronomic identity (Harrington, 2005; Nebioğlu, 2016). 
Danhi (2003) refers to the gastronomic identity of a place as being determined by the use of dominant tastes, techniques and presentations in the recipes in a region. Danhi (2003) pointed that six main elements are critical in shaping a place's gastronomic identity. These factors consist of geographical elements, historical aspects, diversity of ethnicities, culinary customs or etiquette, dominant tastes and recipes. The culinary etiquette, which determines the characteristics of a local cuisine, refers to the eating habits of a certain culture (Danhi, 2003). Rao et al. (2003) argue that some of these dimensions have changed over time. These authors state that there are five dimensions that determine the gastronomic identity: the culinary discourses, the rules of cooking, the different contents, the chef's ability and the structure of the menu (Rao et al., 2003).

Based on the above-mentioned literature, Lai et al. (2018) define the different elements that constitute the gastronomic identity of Australia as including six components. These encompass geographical components, cultural culinary characteristics, aspects related to food consumption as a lifestyle, the quality of the food, the existing restaurants and other dining places and the culinary activities organized. The current study is based on Lai et al.'s conceptualization and aims to measure the gastronomic identity of Gaziantep through perceptions of both tourists and residents.

Regardless of the nature of the destination, taking the views of different stakeholders' groups when marketing the place has become increasingly important (Ferrell et al., 2010; Gundlach \& Wilkie, 2010; Line \& Wang, 2017; Lusch, 2007; Lusch \& Webster, 2011). Haugland et al. (2011) also remark that resources that are available to different individual players may only be turned into specific destination competencies through collaboration and integration of the different actors involved. In this instance, network and stakeholder theories may be used to obtain insights into the mechanisms for collaboration (Haugland et al., 2011) and to look at the destination product from the perspective of the various interested parties. Indeed, stakeholder theory constitutes an approach to marketing in which the destination's stakeholders are taken into account while marketing destinations, instead of focusing on the customer and the market (d'Angella \& Go, 2009). Within this approach, the aim of marketing is not only to please customers, but also to increase the value for all the stakeholders involved (Line \& Wang, 2017). When a destination adopts a market orientation approach that involves multiple stakeholders, its brand identity should be defined taking these different parties into consideration (Garcia et al., 2012; Line and Wang, 2017; Özdemir et al., 2015; Yusof \& Ismail, 2014). In particular, the residents of a city have an important role to 
play in defining the identity of the place (Everett \& Aitchison, 2008). Considering the view of residents who contribute to the creation of the city's character, and tourists, who will choose the destination based on a particular image portrayed (Björk \& Kauppinen-Räisänen, 2016) is also important for Gaziantep. This city identifies itself as a city of gastronomy, focusing its marketing efforts on the tourists' gastronomic experience (Özdemir, 2018).

\section{Gaziantep as a Destination for Gastronomy Tourism}

The popularity of Gaziantep, selected for the UNESCO Creative Cities Network, has been increasing since 2015 (UCCN, n.d.). Gaziantep is a city rich in cultural heritage due to its deep-rooted history. The city is one of the first settlements of Anatolia, being located between Mesopotamia and the Mediterranean, and having witnessed many civilizations and different cultures throughout history. Because the province of Gaziantep was on the Silk Road, and since Arabs, Kurds, Armenians and Turkmens lived together in this city during the Ottoman period, the destination may be considered as a place of cultural interaction (Aksoy \& Sezgi, 2015). This diversity enriches the cultural texture of the city and this richness is reflected in the city's cuisine (GMM, 2019; Koçoğlu, 2019; Özdemir, 2018). This cultural wealth results in more than 400 types of food in Gaziantep's cuisine, of which 291 are registered through geographical indication (GMM, 2019). Gaziantep's dishes have an important position in Turkish and World cuisines. Baklava, Katmer, Beyran, and various types of kebabs are among the most familiar foods of the city (GMM, 2019). Pistachio is a local product that is registered through geographical indication and that is used in food and many kinds of sweets in Gaziantep (TPTO, 2019). This culinary wealth has allowed the city to be chosen in 2015 as a city of gastronomy under the UCCN framework.

In addition to its culinary richness, Gaziantep is also endowed with many historical and cultural resources that add to the city's attractiveness. For example, the Zeugma Mosaic Museum is the biggest mosaic and openair museum in the world (GMM, 2019), exhibiting spectacular mosaics. Gaziantep also has a rich culture in terms of traditional handicrafts. Among these, copper has an important place in the city's history and culture (Özdemir \& Kaya, 2011). Other traditional handicrafts in Gaziantep include embroidery of silver, weaving of carpets and rugs, textile silk weaving, inlaying of mother of pearl, production of clay-based kitchen materials, etc. (GMM, 2019). 
Before being selected to the UNESCO Creative Cities Network in 2015, Gaziantep was mainly known for its industrial activity. The inscription of the city in the Creative Cities Network has contributed to raise awareness about the city and its gastronomical wealth (GCC, 2019). The increasing popularity of Gaziantep as a gastronomic destination has led to a significant growth in the number of tours organized in the city. In this way, almost 600,000 local and foreign tourists visit this magnificent city annually. There are also 15 tourism investment certified hotels in the city, of which 5 have been opened only in recent years (GPDCT, 2019). While most of the restaurants and shops that sell food produce, such as baklava or pistachios, already existed before the popularization of the city as a gastronomy destination, the level of production and revenues of these places has also significantly increased in the last few years (Gaziantep27, 2017; Posta, 2019). Given these characteristics, Gaziantep may be considered as being at the development stage of the destination life-cycle (Butler, 1980), although at certain times during the year the number of tourists significantly exceeds the existing capacity (GPDCT, 2019; Gaziantep27, 2019), showing signs of consolidation. Gaziantep is also currently relying significantly on its culinary attributes to promote and differentiate itself from other competing cities.

Therefore, the city of Gaziantep provides a suitable setting to investigate gastronomic identity of various tourists and residents in a destination that incorporates a wealth of both culinary and non-culinary cultural elements. While many researches have focused on the view of tourists (Chi et al., 2013; Correia et al., 2008; Horng et al., 2012; JiménezBeltrán et al., 2016b; Kivela \& Crotts, 2006) some papers also address the perspective of the residents (Hillel et al., 2013). The current research aims to investigate the views of both stakeholder groups, tourists and residents, looking at how the destination's culinary resources come together to define Gaziantep's gastronomic identity. The paper provides a more comprehensive and holistic view as it examines gastronomic identity from a wider perspective.

\section{METHODOLOGY}

The study aims to explore the attributes of the gastronomic identity of Gaziantep as a tourist destination, looking at the dimensionality and measurement of this concept. In addition, differences between the perceptions of tourists and residents are examined. Gaziantep's population is almost 2 million and according to Provincial Culture 
Tourism Directorate's information, which was obtained via official correspondence, 560,000 domestic tourists (out of a total of 600,000 tourists) have visited the city in 2018. The population of the research consists of local people and visitors to Gaziantep. The data were collected between March and April 2019. Local people were administered an online questionnaire, which was shared through social media accounts using a combination of convenience and snowball sampling. Care was ensured to access residents from varied backgrounds and who are not working in the tourism industry, since it was thought that those working on tourism would have a different view of the city. The tourists that participated in the research include only domestic tourists, who were accessed at the city's main touristic attractions in Gaziantep. The locations where these respondents were approached include the Elmacı Bazaar and the Zeugma Mosaic Museum. These respondents were asked to fill in a paper-based format of the questionnaire. In total, 214 questionnaires from tourists and 164 from residents were obtained. Table 1 provides information on the profile of both samples separately.

Table 1. Frequency distribution of demographic profiles of participants

\begin{tabular}{lcc}
\hline & Residents & Visitors \\
\hline Gender & 66 & 89 \\
Male & 98 & 125 \\
Female & & \\
Age & 50 & 48 \\
$18-25$ & 45 & 67 \\
$26-35$ & 43 & 56 \\
$36-45$ & 17 & 32 \\
$46-55$ & 9 & 11 \\
56 and up & & \\
Education Level & 14 & 21 \\
Elementary & 39 & 57 \\
High School & 41 & 42 \\
Associate Degree & 56 & 85 \\
Undergraduate & 14 & 9 \\
Graduate & & \\
Marital Status & 68 & $\mathbf{2 1 4}$ \\
Single & 91 & 57 \\
Married & 5 & $\mathbf{1 6 4} 2$ \\
Other & & 5 \\
\hline TOTAL & & \\
\hline
\end{tabular}


In the current study in order to measure the gastronomic identity of Gaziantep, the scale from Lai et al (2018) was used. In order to adapt the measure of gastronomic identity to the particular situation of Gaziantep interviews with five experts were carried out. These experts included respondents from the local government and from the tourism sector from five-star hotels and first-class restaurants. The interviews revolved around the main gastronomical aspects of Gaziantep according to the interviewees. The resulting questionnaire form was piloted before being applied to the target group.

As in the original scale from Lai et al. (2018), the measure of gastronomic identity used consists of 6 dimensions; geographic environment, food culture, food as lifestyle, food quality, dining places/restaurants and food activities. All the items in the utilized measurement tool were rated using a seven-point Likert scale. The data were analysed using SPSS software and AMOS version 25.

\section{FINDINGS}

In order to explore the dimensionality of the scale, an Exploratory Factor Analysis (EFA) using the principal components method was carried out. The adequacy of the sample and the suitability of the data is confirmed through the KMO (Kaiser-Meyer-Olkin) test, which is 0.954, and the Barlett's Test of Sphericity, which is significant $(p=0.00)$. This analysis was also used to refine the scale and some of the items with low commonalities were eliminated. The final analysis revealed a four-factor solution that explains $73.89 \%$ of the variation. The factors obtained are named as "Gastronomic culture and reputation", "Food quality", "Food outlets" and "Gastronomic activities". Detailed information on each of the factors may be seen in Table 2 .

As observed in Table 2, the means of the various items are high, all of them above 4.6. The highest means correspond to those items that are under the gastronomic culture and reputation dimension. In contrast, the lowest means are those of the items concerning gastronomic activities in Gaziantep, such as festivals and cooking classes, as well as those pertaining to the language of the menus in the restaurants and the availability of fresh produce. Nevertheless, these means are also high. 
Table 2. Gastronomic Identity: Exploratory Factor Analysis

\begin{tabular}{|c|c|c|c|c|c|c|}
\hline Items & $\begin{array}{l}\text { Common- } \\
\text { alities }\end{array}$ & Mean & $\begin{array}{c}\text { Factor } \\
1 \\
\end{array}$ & $\begin{array}{c}\text { Factor } \\
2\end{array}$ & $\begin{array}{c}\text { Factor } \\
3\end{array}$ & $\begin{array}{c}\text { Factor } \\
4\end{array}$ \\
\hline \multicolumn{7}{|l|}{ Gastronomic culture and reputation } \\
\hline $\begin{array}{l}\text { Gaziantep has its own unique food history, } \\
\text { tradition and culture (G4) }\end{array}$ & .814 & 5.91 & .831 & & & \\
\hline $\begin{array}{l}\text { Gaziantep offers an attractive local food culture } \\
\text { (G5) }\end{array}$ & .806 & 5.93 & .812 & & & \\
\hline $\begin{array}{l}\text { Gaziantep offers local dishes and local cuisine } \\
\text { with a true local flavour (G6) }\end{array}$ & .835 & 5.92 & .810 & & & \\
\hline $\begin{array}{l}\text { Gaziantep offers a wide variety of foods and } \\
\text { dishes (G8) }\end{array}$ & .824 & 5.88 & .808 & & & \\
\hline $\begin{array}{l}\text { Gaziantep's food and cuisine are well-known } \\
\text { and recognized (G10) }\end{array}$ & .812 & 5.92 & .795 & & & \\
\hline $\begin{array}{l}\text { Gaziantep offers unique food with cuisine styles } \\
\text { unique to Gaziantep (G7) }\end{array}$ & .797 & 5.89 & .795 & & & \\
\hline $\begin{array}{l}\text { Gaziantep is well-known as a pistachio } \\
\text { producer (G3) }\end{array}$ & .701 & 5.75 & .780 & & & \\
\hline $\begin{array}{l}\text { Food culture is an essential element in } \\
\text { Gaziantep's lifestyle (G11) }\end{array}$ & .792 & 5.96 & .771 & & & \\
\hline $\begin{array}{l}\text { Gaziantep offers authentic food using local } \\
\text { ingredients (G9) }\end{array}$ & .764 & 5.89 & .745 & & & \\
\hline $\begin{array}{l}\text { Gaziantep's food is delicious, colourful, } \\
\text { aromatic, and tasty (G14) }\end{array}$ & .763 & 5.80 & .709 & & & \\
\hline \multicolumn{7}{|l|}{ Food quality } \\
\hline $\begin{array}{l}\text { Gaziantep offers healthy and nutritious food } \\
\text { (G17) }\end{array}$ & .769 & 5.08 & & .772 & & \\
\hline $\begin{array}{l}\text { Gaziantep offers a high standard of } \\
\text { safety/hygienic food (G16) }\end{array}$ & .720 & 5.10 & & .742 & & \\
\hline $\begin{array}{l}\text { Gaziantep offers fresh produce (e.g. fresh fruits, } \\
\text { vegetables, and high-grade meat) (G18) }\end{array}$ & .707 & 4.95 & & .737 & & \\
\hline $\begin{array}{l}\text { Gaziantep produces high-quality food with food } \\
\text { quality labels (G15) }\end{array}$ & 639 & 5.31 & & 630 & & \\
\hline $\begin{array}{l}\text { Gaziantep's cuisine expresses the eating habits } \\
\text { of all social classes (G12) }\end{array}$ & .523 & 5.31 & & .564 & & \\
\hline \multicolumn{7}{|l|}{ Food outlets } \\
\hline $\begin{array}{l}\text { Gaziantep offers restaurant menus in Turkish } \\
\text { and other languages (G27) }\end{array}$ & .782 & 4.65 & & & .853 & \\
\hline $\begin{array}{l}\text { Gaziantep offers friendly service personnel in its } \\
\text { restaurants (G28) }\end{array}$ & .664 & 5.00 & & & .687 & \\
\hline Gaziantep offers easy access to restaurants (G29) & .686 & 5.11 & & & .677 & \\
\hline $\begin{array}{l}\text { Gaziantep offers attractive markets that provide } \\
\text { farm-direct fresh produce (G26) }\end{array}$ & .595 & 5.01 & & & 649 & \\
\hline \multicolumn{7}{|l|}{ Gastronomic activities } \\
\hline $\begin{array}{l}\text { Gaziantep offers various food festivals/events } \\
\text { (G22) }\end{array}$ & .803 & 4.97 & & & & .833 \\
\hline $\begin{array}{l}\text { Gaziantep offers cooking classes that involve } \\
\text { tourists cooking with local chefs and learning } \\
\text { how to cook local dishes (G21) }\end{array}$ & .723 & 4.66 & & & & .762 \\
\hline Chronbach's Alpha (Total $=.952)$ & & & .968 & .871 & .830 & .713 \\
\hline Percentage Variance $($ Total $=73.89)$ & & & 52.89 & 13.04 & 4.37 & 3.59 \\
\hline
\end{tabular}

Principal Component Analysis; Rotation Method: Equamax with Kaiser Normalization

Kaiser-Meyer-Olkin Measure of Sampling Adequacy $=0.954$; Barlett's Test of Sphericity: Significance $=0.000$

Only factor loadings greater than 0.5 are included in the table 


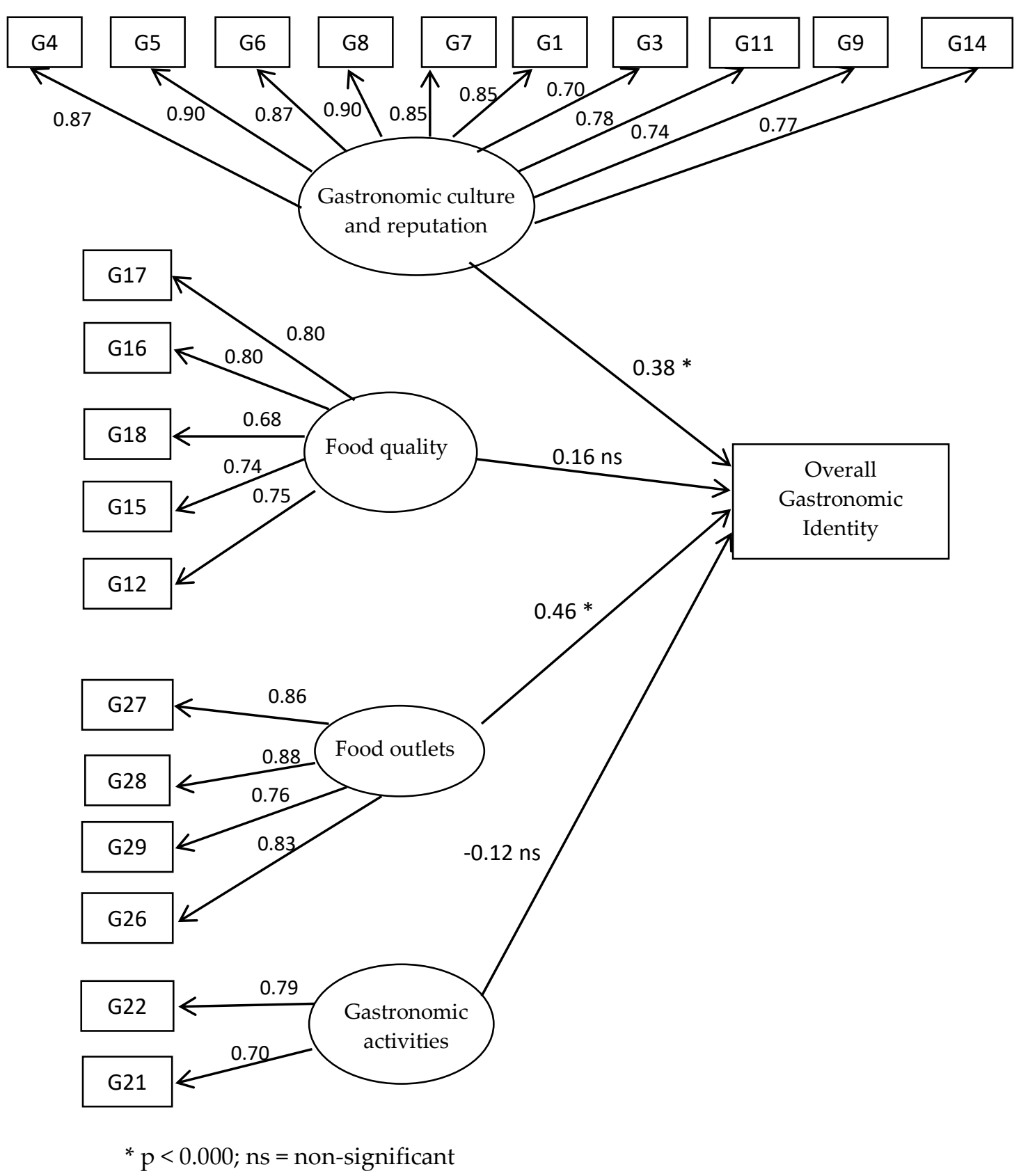

Figure 1. CFA Measurement Model

Confirmatory factor analysis (CFA) was used in order to test the dimensionality of the scale obtained through the EFA. The results of this analysis are shown in Figure 1 and Table 3. The reliability is confirmed, as the Composite Reliability (CR) figures are all above 0.8 or close to it, indicating the internal consistency of the constructs (Hatcher, 1994). This finding is also supported by the Cronbach's Alpha figures obtained for each of the dimensions of gastronomic identity. In addition, the Average 
Variance Extracted (AVE) is greater than 0.5 for all constructs, except in the case of Food quality, which is very close (Hatcher, 1994). This finding confirms the convergent validity of the various dimensions of gastronomic identity of Gaziantep. The goodness of fit of the model is also confirmed since the AGFI is 0.90 , the CFI is 0.98 , the GFI is 0.92 and the RMSEA is 0.05 . These numbers are all within the recommended critical values (Bollen, 1989; Engel et al., 2003). The CFA Measurement Model is shown in Figure 1 and Table 3.

Table 3. Confirmatory Factor Analysis of Gastronomic Identity

\begin{tabular}{|c|c|c|c|c|c|c|}
\hline & & & & $\begin{array}{c}\text { Standardized } \\
\text { Regression } \\
\text { Weights } \\
\end{array}$ & $\begin{array}{c}\mathrm{t}- \\
\text { value }\end{array}$ & $\mathbf{p}$ \\
\hline G4 & $\leftarrow$ & Gastronomic culture and rep & ation & 0.871 & & \\
\hline G5 & $\leftarrow$ & Gastronomic culture and rep & ation & 0.905 & 25.60 & 0.000 \\
\hline G6 & $\leftarrow$ & Gastronomic culture and rep & ation & 0.868 & 27.87 & 0.000 \\
\hline G8 & $\leftarrow$ & Gastronomic culture and rep & ation & 0.905 & 25.59 & 0.000 \\
\hline G7 & $\leftarrow$ & Gastronomic culture and rep & ation & 0.855 & 22.66 & 0.000 \\
\hline G10 & $\leftarrow$ & Gastronomic culture and rep & ation & 0.848 & 22.38 & 0.000 \\
\hline G3 & $\leftarrow$ & Gastronomic culture and rep & ation & 0.703 & & \\
\hline G11 & $\leftarrow$ & Gastronomic culture and rep & ation & 0.776 & 13.83 & 0.000 \\
\hline G9 & $\leftarrow$ & Gastronomic culture and rep & ation & 0.743 & 13.13 & 0.000 \\
\hline G14 & $\leftarrow$ & Gastronomic culture and rep & ation & 0.766 & 13.62 & 0.000 \\
\hline G17 & $\leftarrow$ & Food quality & & 0.798 & 13.10 & 0.000 \\
\hline G16 & $\leftarrow$ & Food quality & & 0.799 & & \\
\hline G18 & $\leftarrow$ & Food quality & & 0.677 & 13.28 & 0.000 \\
\hline G15 & $\leftarrow$ & Food quality & & 0.738 & & \\
\hline G12 & $\leftarrow$ & Food quality & & 0.753 & 12.34 & 0.000 \\
\hline G27 & $\leftarrow$ & Restaurants and food outlets & & 0.863 & 23.16 & 0.000 \\
\hline G28 & $\leftarrow$ & Restaurants and food outlets & & 0.884 & 24.20 & 0.000 \\
\hline G29 & $\leftarrow$ & Restaurants and food outlets & & 0.763 & 22.23 & 0.000 \\
\hline G26 & $\leftarrow$ & Restaurants and food outlets & & 0.827 & 21.30 & 0.000 \\
\hline G22 & $\leftarrow$ & Gastronomic activities & & 0.792 & 16.02 & 0.000 \\
\hline G21 & $\leftarrow$ & Gastronomic activities & & 0.704 & 12.50 & 0.000 \\
\hline Overall gastronomic identity & $\leftarrow$ & Gastronomic culture and rep & ation & 0.382 & 7.27 & 0.000 \\
\hline Overall gastronomic identity & $\leftarrow$ & Food quality & & 0.164 & 1.57 & 0.117 \\
\hline Overall gastronomic identity & $\leftarrow$ & Restaurants and food outlets & & 0.456 & 4.17 & 0.000 \\
\hline Overall gastronomic identity & $\leftarrow$ & Gastronomic activities & & -0.120 & -1.18 & 0.237 \\
\hline \multicolumn{6}{|c|}{ Chi-square $=353.578 ;$ Degrees of freedom $=183 ;$ Probability level $=0.00$} & \\
\hline & & $\mathrm{CR}$ & AVE & \multicolumn{3}{|c|}{ Cronbach's Alpha } \\
\hline \multicolumn{2}{|c|}{ Gastronomic culture and reputation } & 0.94 & 0.62 & \multicolumn{3}{|c|}{0.968} \\
\hline \multicolumn{2}{|l|}{ Food quality } & 0.82 & 0.48 & \multicolumn{3}{|c|}{0.871} \\
\hline \multicolumn{2}{|l|}{ Restaurants and food outlets } & 0.81 & 0.53 & \multicolumn{3}{|c|}{0.830} \\
\hline \multicolumn{2}{|l|}{ Gastronomic activities } & 0.78 & 0.64 & \multicolumn{3}{|c|}{0.713} \\
\hline
\end{tabular}


The gastronomic identity scale is defined as a second order formative construct (first order formation and second order reflectivity). In addition, the four dimensions obtained in the EFA are confirmed through the CFA. However, of the four different aspects of gastronomic identity only two of them form the overall gastronomic identity of Gaziantep. That is, the gastronomic identity of Gaziantep is formed by its restaurants and food outlets (weight of $0.456 ; \mathrm{p}<0.000$ ), as well as by its gastronomic culture and reputation (weight of 0.382; $\mathrm{p}<0.000$ ). In contrast, for Gaziantep, the food quality and gastronomic activities dimensions do not significantly form its overall gastronomic identity. This finding may be explained by the fact that these dimensions are not strongly associated to Gaziantep, as for example activities related to its food and gastronomy are not very well known and its gastronomy festival has only been implemented since 2018 (Hurriyet, 2018). This result may be different for other destinations in which these dimensions may be more influential in the formation of the place's gastronomic identity.

In order to determine whether there are differences between the perspective of the tourists and locals concerning Gaziantep's gastronomic identity, an independent samples t-test was applied. According to the findings, a significant difference between the groups is found in the food quality and gastronomic activities dimensions (Table 4). That is, residents of Gaziantep perceive food quality (mean $=5.39)$ significantly $(p=0.019)$ higher than tourists $(m e a n=5.11)$. Similarly, the local people see Gaziantep's gastronomic activities (mean $=4.62)$ as being significantly $(p=$ 0.032 ) more numerous than the visitors (mean=4.39). However, as seen in Table 4, there is no significant difference between the groups in relation to the gastronomic culture and reputation and the restaurants and food outlets dimensions.

Table 4. Differences between residents and tourists

\begin{tabular}{llrrc}
\hline $\begin{array}{l}\text { Dimensions of gastronomic } \\
\text { identity }\end{array}$ & Groups & Mean & t-value & Significance \\
\hline $\begin{array}{l}\text { Gastronomic culture and } \\
\text { reputation }\end{array}$ & $\begin{array}{l}\text { Resident } \\
\text { Tourist }\end{array}$ & $\begin{array}{l}5.74 \\
5.56\end{array}$ & 1.459 & 0.145 \\
\hline Food quality & $\begin{array}{l}\text { Resident } \\
\text { Tourist }\end{array}$ & $\begin{array}{l}5.39 \\
5.12\end{array}$ & 2.352 & 0.019 \\
\hline Food outlets & Resident & 5.17 & 1.174 & 0.241 \\
\hline Gastronomic activities & Tourist & 5.02 & 0.032 \\
\hline
\end{tabular}




\section{CONCLUSIONS, LIMITATIONS AND FURTHER RESEARCH}

This study examines the dimensions of gastronomic identity from the point of view of visitors and residents in Gaziantep. The research establishes the city's gastronomic identity as encompassing four dimensions, namely Gastronomic Culture and Reputation, Food Quality, Food Outlets and Gastronomic Activities. This finding shows a difference between the dimensionality of gastronomic identity in the study of Lai et al. (2018) and that obtained in the current research. In addition, among the four different aspects of gastronomic identity only two of them, food outlets and gastronomic culture and reputation, form Gaziantep's overall gastronomic identity. Thus, for this city, certain aspects in the gastronomic identity scale are not well known to tourists and may not yet be associated to the identity of Gaziantep. This result implies that contextual elements referring to the particular situation of the gastronomic destination may be present and shows the need to adapt existing scales measuring gastronomic identity to the particular situation of that destination. A better understanding of what constitutes gastronomic identity of a place for different types of destinations may be achieved by investigating the topic in more detail, comparing destinations that are both dissimilar and akin. For example, Antakya is another city in Turkey that was chosen in 2017 to be part of UNESCO's UCCN in the field of gastronomy. The comparison of Antakya and Gaziantep would shed light on the construct of gastronomic identity and its dimensionality.

Furthermore, according to the findings in this research, the main difference between visitors and residents concerns perceptions of food quality and gastronomic activities. According to these results, the residents have a more favourable perception of the quality of the food and the variety of activities provided in the city. This difference in perceptions may be due to the local inhabitants being more aware of the city's gastronomic activities and to the existence of several restaurants that cater mainly to the tourists and which may not reflect well Gaziantep's food quality. However, this topic should be investigated further in future research, since it is important for the management of the destination's brand. Indeed, previous studies have stressed the importance of aligning the views of tourists with those of the local people, since a gap in the destination image between the visitors and the residents may result on a lower support of the community for tourism (Compte-Pujol et al., 2018; Ryan \& Aicken, 2010). As branding is also important in order to strengthen the community's sense of identity and pride (Campelo et al., 2014), so in the case of Gaziantep it is paramount that the community's 
positive perceptions concerning the city's gastronomic aspects be also conveyed to the tourists. This result also indicates that in addition to better promoting the city's gastronomic resources to the tourists, it may be necessary to identify gaps between the service that is provided to the tourists and that which is available to the local people.

Thus, as this research points out, the construction of the gastronomic identity of a destination with the purpose of using it for branding purposes needs to incorporate the views of different stakeholder groups and to carefully examine any potential gaps in the perceptions of varied interested parties. In the case of Gaziantep, despite the differences between residents and visitors in the dimensions of food quality and gastronomic activities, differences are not seen in terms of gastronomic culture and reputation, and food outlets. In addition, the means for the various dimensions of gastronomic identity of Gaziantep are very high for both stakeholder groups, especially for the culture and reputation aspect of gastronomic identity. Thus, following Haugland et al. (2011) and Horng and Tsai (2012), gastronomy and culinary resources seem to constitute an important competency of the city, supporting the current promotional efforts being carried out for this destination. Notwithstanding this positive result, attention may need to be paid to further promoting gastronomic activities so that they become associated with the destination's brand and included as part of its identity. A more detailed investigation of the food quality of existing food outlets may also reveal a difference between those establishments that cater to residents and those that are more touristic, thus indicating the need for a more integrated management of culinary resources that are produced by the various individual actors. Such a research should also take into consideration the destination's life cycle stage, as Gaziantep shows signs of moving from a development to a consolidation stage in which some of the food services provided may become more commodified and lose their authentic flavours.

The current investigation is limited in that it includes only the opinions of tourists and local residents. Other influential stakeholders, such as the local government and the private sector are not included in the research. Future studies should be more comprehensive, including these important interested parties, since the destination's brand identity should ideally be constructed based on a shared view of various stakeholders (Yusof \& Ismail, 2014). In addition, the gastronomic identity should also be identified as part of the overall branding strategy for the destination (Okumuş \& Çetin, 2018). 


\section{REFERENCES}

Aksoy, M., \& Sezgi, G. (2015). Gastronomy tourism and South-eastern Anatolia region gastronomic elements. Journal of Tourism and Gastronomy Studies, 3(3), 79-89.

Barney, J. B. (1996). The resource-based theory of the firm. Organization Science, 7(5), 469470.

Birdir, K. Karakan, İ. H., \& Çolak, O. (2015). SWOT Analysis of Gaziantep province in terms of tourism and suggestions for the development of tourism. Journal of Travel and Hospitality Management, 13(1), 77-92.

Björk, P., \& Kauppinen-Räisänen, H. (2016). Local food: A source for destination attraction. International Journal of Contemporary Hospitality Management, 28(1), 177194.

Bollen, K. A. (1989). Structural Equations with Latent Variables. NY: Wiley

Boyne, S., Hall, D., \& Williams, F., (2003). Policy, support and promotion for food related tourism initiatives: A marketing approach to regional development. Journal of Travel \& Tourism Marketing, 14(3-4), 131-154.

Braun, E., Kavaratzis, M., \& Zenker, S. (2013). My city-my brand: The different roles of residents in place branding. Journal of Place Management and Development, 6(1), 1828.

Buhalis, D. (2000). Marketing the competitive destination of the future. Tourism management, 21(1), 97-116.

Butler, R. (1980). The Concept of a Tourist Area Cycle of Evolution: Implications for Management of Resources. Canadian Geographer, 24(1): 5-2.

Campelo, A., Aitken, R., Thyne, M., \& Gnoth, J. (2014). Sense of place: The importance for destination branding. Journal of Travel Research, 53(2), 154-166.

Chi, C. G. Q., Chua, B. L., Othman, M., \& Karim, A. S. (2013). Investigating the structural relationships between food image, food satisfaction, culinary quality, and behavioral intentions: The case of Malaysia. International Journal of Hospitality $\mathcal{E}$ Tourism Administration, 14(2), 99-120.

Cohen, E. (2003). Tourism and gastronomy. Annals of Tourism Research, 31(3), 731-733.

Compte-Pujol, M., de San Eugenio-Vela, J., \& Frigola-Reig, J. (2018). Key elements in defining Barcelona's place values: The contribution of residents' perceptions from an internal place branding perspective. Place Branding and Public Diplomacy, 14(4), 245-259.

Correia, A., Moital, M., Ferreira da Costa, C., \& Peres, R. (2008). The determinants of gastronomic tourists' satisfaction: A second-order factor analysis. Blackwell Publishing Journal of Foodservice, 19, 164-176.

D'Angella, F., \& Go, F. M. (2009). Tale of two cities' collaborative tourism marketing: Towards a theory of destination stakeholder assessment. Tourism Management, 30(3), 429-440.

Danhi, R. (2003). What is your country's culinary identity? Culinology Currents, Winter 2003, 4-5.

Duarte Alonso, A. (2017). Exploring a developing tourism industry: A resource-based view approach. Tourism Recreation Research, 42(1), 45-58.

Duarte Alonso, A., Kok, S., \& O'Brien, S. (2018). 'We are only scratching the surface'- A resource-based and dynamic capabilities approach in the context of culinary tourism development. Tourism Recreation Research, 43(4), 511-526.

Encyclopaedia Britannica. (2019). The definition of gastronomy. Retrieved May 01, 2019, from https://www.britannica.com/topic/gastronomy. 
Engel, K. S., Moosbrugger, H., \& Müller, H. (2003). Evaluating the fit of structural equation models: Tests of significance and descriptive goodness-of-fit measures. Methods of Psychological Research Online, 8(2), 23-74

Eröz, S. S., \& Doğubay, M. (2012). Turistik ürün tercihinde sosyal medyanın rolü ve etik ilişkisi. Dokuz Eylül Üniversitesi İktisadi ve İdari Bilimler Fakültesi Dergisi, 27(1), 133157.

Everett, S., \& Aitchison, C. (2008). The role of food tourism in sustaining regional identity: A case study of Cornwall, South West England. Journal of Sustainable tourism, 16(2), 150-167.

Ferrell, O. C., Gonzalez-Padron, T. L., Hult, T. M., \& Maignan, I. (2010). From marketing orientation to stakeholder orientation. Journal of Public Policy Marketing, 29(1), 9396.

Fox, R. (2007). Reinventing the gastronomic identity of Croatian tourist destinations. Science Direct Hospitality Management, 26, 546-559.

Garcia, J. A., Gomez, M., \& Molina, A. (2012). A Destination-branding model: An Empirical analysis based on stakeholders. Tourism Management, 33(3), 646-661.

Gaziantep27 (2019, March 12). Otellerde yer yok. Retrieved November 22, 2019, from https://www.gaziantep27.net/otellerde-yer-yok-527327h.htm

Gaziantep27 (2017). Baklavanın ünü sınırları aşıyor. Retrieved November 22, 2019, from https://www.gaziantep27.net/baklavanin-unu-sinirlari-asiyor-507803h.htm

GCC, Gaziantep Chamber of Commerce, (2019). Gaziantep'te Turizm. Retrieved November 19, 2019, from https://www.gto.org.tr/tr/genel-sayfa/turizm-5.html

GMM, Gaziantep Metropolitan Municipality, (2019). Gaziantep City of History and Culture.

GPDCT (2019). Gaziantep Provincial Directorate of Culture and Tourism.

Gundlach, G. T., \& Wilkie, W. L. (2010). Stakeholder marketing: Why 'stakeholder' was omitted from the American Marketing Association's official 2007 definition of marketing and why the future is bright for stakeholder marketing. Journal of Public Policy \& Marketing, 29(1), 89-92.

Harrington, R. J. (2005). Defining Gastronomic Identity: The impact of environment and culture on prevailing components, texture and flavours in wine and food. Journal of Culinary Science and Technology, 4(2/3), 129-152.

Harrington, R. J., \& Ottenbacher, M.C. (2010). Culinary Tourism-A Case Study of the Gastronomic Capital. Journal of Culinary Science \& Technology 8(1),14-32.

Hatcher, L. (1994). A Step-By-Step Approach to Using SAS System for Factor Analysis and Structural Equation Modelling. Cary, NC: SAS Institute Inc.

Haugland, S. A., Ness, H., Grønseth, B. O., \& Aarstad, J. (2011). Development of Tourism Destinations: An Integrated Multilevel Perspective. Annals of Tourism Research, 38(1), 268-290.

Hillel, D., Belhassen, Y., \& Shani, A. (2013). What makes a gastronomic destination attractive? Evidence from the Israeli Negev. Tourism Management, 36, 200-209.

Hjalager, A. M., \& Richards, G. (2002). Tourism and Gastronomy. Routledge.

Horng, J. S., Liu C. H., Chiu, H. Y., \& Tsai, C. Y. (2012). The role of international tourist perceptions of brand equity and travel intention in culinary tourism. The Service Industries Journal, 32(1)6, 2607-2621.

Horng, J. S., \& Tsai, C. T. (2010). Government websites for promoting East Asian culinary tourism: A cross-national analysis. Tourism Management, 31, 74-85. 
Horng, J. S., \& Tsai, C. T. (2012). Constructing indicators of culinary tourism strategy: An application of resource-based theory. Journal of Travel \& Tourism Marketing, 29(8), 796-816.

Hurriyet Newspaper. (2018). Gaziantep'te “Gastronomi" Festivali. Retrieved November 22, 2019, from http://www.hurriyet.com.tr/gaziantepte-gastronomi-festivali40906579.

Jiménez-Beltrán, F., López-Guzmán, T., \& González Santa Cruz, F. (2016a). Analysis of the relationship between tourism and food culture. Sustainability, 8(5), 418.

Jiménez Beltrán, F.J., López-Guzmán, T. \& Santa Cruz, F. G. (2016b). Gastronomy and Tourism: Profile and motivation of international tourism in the city of Córdoba, Spain. Journal of Culinary Science \& Technology 14(4), 347-362.

Kivela, J. (2017). Gastronomy tourism: Croatia, a land of wine and plenty, or beyond pizza and grill! In L. Dwyer, R. Tomljenović, S. Čorak (Eds.), Evolution of Destination Planning and Strategy (pp. 265-278). Palgrave Macmillan, Cham. DOI 10.1007/978-3-319-42246-6_13

Kivela, J., \& Crotts, J. C. (2005). Gastronomy tourism: A meaningful travel market segment. Journal of Culinary Science \& Technology, 4(2-3), 39-55.

Kivela, J., \& Crotts, C, (2006). Tourism and gastronomy: Gastronomy's influence on how tourists experience a destination. Journal of Hospitality \& Tourism Research, 30(3), $354-377$.

Koçoğlu, C. M. (2019). Yerli turistlerin gastronomi turizmine yönelik tutumlarının demografik özellikler açısından incelenmesi: Gaziantep örneği. Gastroia: Journal of Gastronomy and Travel Research, 3(2), 366-380.

Kong, W. H., du Cros, H., \& Ong, C. E. (2015). Tourism destination image development: A lesson from Macau. International Journal of Tourism Cities, 1(4), 299-316.

Lai, M. Y., Khoo-Lattimore, C., \& Wang, Y. (2018). A perception gap investigation in to food and cuisine image attributes for destination branding from the host perspective: The case of Australia. Tourism Management, 69, 579-595.

Lin, Y. C., Pearson, T. E., \& Cai, L. A. (2011). Food as a form of destination identity: A tourism destination brand perspective. Tourism and Hospitality Research, 11(1), 3048.

Line, N. D., \& Wang, Y. (2017). A multi-stakeholder market-oriented approach to destination marketing. Journal of Destination Marketing \& Management, 6(1), 84-93.

Lusch, R. F. (2007). Marketing's evolving identity: Defining our future. Journal of Public Policy \& Marketing, 26(2), 261-268.

Lusch, R. F., \& Webster, F. E., Jr. (2011). A stakeholder-unifying, co-creation philosophy for marketing. Journal of Macro Marketing, 31(2), 129-134

Long, L. M. (Ed.). (2004). Culinary tourism. Kentucky: The University Press of Kentucky.

McKercher, B., Okumus, F., \& Okumus, B. (2008). Food tourism as a viable market segment: It's all how you cook the numbers! Journal of Travel $\mathcal{E}$ Tourism Marketing, 25(2), 137-148.

Nebioğlu, O. (2016). A qualitative research on gastronomic identity and gastronomic tourism products typology: Alanya sample. Journal of Tourism and Gastronomy Studies, 5(2), 39-60.

Okumus, B., \& Cetin, G. (2018). Marketing Istanbul as a culinary destination. Journal of Destination Marketing \& Management, 9, 340-346.

Okumuş, B., Köseoğlu, M. A., \& Ma, F. (2018). Food and gastronomy research in tourism and hospitality: A bibliometric analysis. International Journal of Hospitality Management, 73, 64-74. 
Okumuş, B., Okumuş, F., \& McKercher, B. (2007). Incorporating local and international cuisines in the marketing of tourism destinations: The cases of Hong Kong and Turkey. Tourism Management, 28(1), 253- 261

Özdemir, G., Yılmaz, M., Yalçın, M., \& Alvarez, D. M. (2015). Stakeholders' perception of Istanbul's historical peninsula as a sustainable destination. Tourism Planning $\mathcal{E}$ Development, 12(1), 87-98.

Özdemir, M., \& Kaya, F. O. (2011). Today, coppersmith's business in the city of Gaziantep. Gaziantep University Social Science Journal, 10(3), 1149- 1170.

Özdemir, P. (2018). Branding a millennia-old Turkish city: Case of Gaziantep. ilef journal, 5(2), 121-140.

Posta (2019, June 1). Siparişler Geri Çevriliyor. Retrieved November 22, 2019, from https://www.posta.com.tr/antep-baklavasinda-siparisler-geri-cevriliyor-2163017

Presenza, A., \& Del Chiappa, G. (2013). Entrepreneurial strategies in leveraging food as a tourist resource: A cross-regional analysis in Italy. Journal of Heritage Tourism, 8(23), 182-192.

Rao, H., Monin, P., \& Durand, R. (2003). Institutional change in Toque Ville: Nouvellecuisine as an identity movement in French gastronomy. The American Journal of Sociology, 108(4), 795-843.

Riley, M. (1994). Marketing out: the influence of social culture and innovation. British Journal of Food, 96(10), 15-19.

Rodríguez-Díaz, M., \& Espino-Rodríguez, T. F. (2008). A model of strategic evaluation of a tourism destination based on internal and relational capabilities. Journal of Travel Research, 46(4), 368-380.

Ryan, C., \& Aicken, M. (2010). The destination image gap-visitors' and residents' perceptions of place: evidence from Waiheke Island, New Zealand. Current Issues in Tourism, 13(6), 541-561.

Sánchez-Cañizares, S. M., \& López-Guzmán, T. (2012). Gastronomy as a tourism resource: Profile of the culinary tourist. Current Issues in Tourism, 15(3), 229-245.

Scarpato, R. (2000). New global cuisine: The perspective of postmodern gastronomy studies. Unpublished master's thesis, RMIT University, Melbourne, Australia.

Scarpato, R. (2001). Figli dei fiori? No, di cavoli e fornelli. Gambero Rosso, Monthly, April, 41-43.

Sirše, M. C. J. (2014). Gastronomic cities: City strategy on gastronomy as a tool for tourism and employment development. Baseline study, connecting cities building successes, European Union, March 2014.

Sormaz, Ü., Akmeseb, H., Gunes, E., \& Aras, S. (2016). Gastronomy in Tourism. Procedia Economics and Finance, 39(2016), $725-730$.

Stavrianea, A., Dipidis, C., \& Siomkos, G. (2017). Gastronomy tourism: An examination of the "Greek Breakfast Initiative" potential. In N. Tsounis \& A. Vlachvei (Eds.), Advances in Applied Economic Research (pp. 841-848). Springer, Cham.

Symons, M. (1998). The pudding that took a thousand cooks: The story of cooking in civilisation and daily life. Melbourne: Viking.

Şahin, G. G., \& Ünver, G. (2015). Destinasyon pazarlama aracı olarak gastronomi turizmi: İstanbul'un gastronomi turizmi potansiyeli üzerine bir araştırma. Journal of Tourism and Gastronomy Studies, 3(2), 63-73.

Tuç, Z., \& Özkanlı, O. (2017). Resource about reshaping of food and beverage culture by social media: Sample Gaziantep City. Journal of Urban Culture and Management, 10(2), 216-239. 
TPTO (2019). Turkish Patent and Trademark Office. Retrieved April 22, 2019, from https://www.turkpatent.gov.tr/TURKPATENT/geographicalRegisteredList/.

UCCN (n.d.). UNESCO Creative Cities Network. Retrieved April 22, 2019, from https://en.unesco.org/creative-cities/gaziantep.

UNWTO, World Tourism Organisation. (2016). Gastronomy Tourism Network. Retrieved April 22, 2019, from http://affiliatemembers.unwto.org/content/gastronomytourism-network

UNWTO, World Tourism Organisation, (2017). Second Global Report on Gastronomy Tourism. Retrieved April 01, 2019, from http://cf.cdn.unwto.org/sites/all/files/pdf/gastronomy_report_web.pdf

Williams, H. A., Williams Jr, R. L., \& Omar, M. (2014). Gastro-tourism as destination branding in emerging markets. International Journal of Leisure and Tourism Marketing, 4(1), 1-18.

Xiaomin, C. (2017). "City of Gastronomy" of UNESCO Creative Cities Network: From international criteria to local practice. Social Systems Studies, 55-67.

Yusof, M. F. M., \& Ismail, H. N. (2014). Destination branding identity from the stakeholders' perspectives. International Journal of Built Environment and Sustainability, 1(1), 71-75. 